\title{
Role of Nitric Oxide in Experimental Obliterative Bronchiolitis (Chronic Rejection) in the Rat
}

\author{
Erkki A. Kallio, ${ }^{\star}$ Petri K. Koskinen, ${ }^{\star}$ Einari Aavik, ${ }^{\star}$ Kirsi Vaali, ${ }^{\star}$ and Karl B. Lemstöm \\ *Cardiopulmonary Research Group of Transplantation Laboratory, Haartman Institute, University of Helsinki and Helsinki University \\ Central Hospital; and ${ }^{\ddagger}$ Institute of Biomedicine, Department of Pharmacology and Toxicology, FIN-00014 University of Helsinki, \\ Helsinki, Finland
}

\begin{abstract}
The role of nitric oxide in obliterative bronchiolitis development, i.e., chronic rejection, was investigated in the heterotopic rat tracheal allograft model. An increase in the intragraft inducible nitric oxide synthase (iNOS) mRNA and mononuclear inflammatory cell iNOS immunoreactivity was demonstrated during progressive loss of respiratory epithelium and airway occlusion in nontreated allografts compared to syngeneic grafts. In nontreated allografts, however, intragraft nitric oxide production was decreased, most likely because of loss of iNOS epithelial expression. Treatment with aminoguanidine, a preferential inhibitor of inducible nitric oxide synthase, was associated with enhanced proliferation of $\alpha$-smooth muscle actin immunoreactive cells and the intensity of obliterative bronchiolitis early after transplantation. Aminoguanidine treatment did not affect iNOS mRNA synthesis or intragraft nitric oxide production, but decreased iNOS immunoreactivity in smooth muscle cells. Treatment with L-arginine, a precursor of nitric oxide, significantly reduced obliterative changes. L-arginine supplementation enhanced intragraft iNOS mRNA synthesis and iNOS immunoreactivity in capillary endothelial and smooth muscle cells as well as intragraft nitric oxide production. Immunohistochemical analysis of allografts showed that neither iNOS inhibition nor supplementation of the nitric oxide pathway affected the number of graft-infiltrating CD4 + and CD8 + T cells, ED1 + and ED3 + macrophages, immune activation with expression of IL-2R or MHC class II, or production of macrophage or Th1 cytokines. In contrast, L-arginine treatment was associated with increased staining for Th2 cytokines IL-4 and IL-10. In conclusion, this study demonstrates that nitric oxide has a protective role in obliterative bronchiolitis development in this model, and suggests that nitric oxide either directly or indirectly inhibits smooth muscle cell proliferation and modulates im-
\end{abstract}

This work was presented as an abstract at The 2nd International Symposium of the Etiology and Pathobiology of Transplant Vascular Sclerosis in Southhampton, Bermuda on March 5-9, 1997.

Address correspondence to Dr. Erkki Kallio, Transplantation Laboratory, P.O. Box 21 (Haartmaninkatu 3), FIN-00014 University of Helsinki, Finland. Phone: +358-9-1912-6596; FAX: +358-9-2411227; E-mail: erkki.kallio@helsinki.fi

Received for publication 27 May 1997 and accepted in revised form 16 October 1997.

J. Clin. Invest.

(C) The American Society for Clinical Investigation, Inc. 0021-9738/97/12/2984/11 \$2.00

Volume 100, Number 12, December 1997, 2984-2994

http://www.jci.org mune response towards Th2 cytokines. (J. Clin. Invest. 1997. 100:2984-2994.) Key words: inducible nitric oxide synthase • L-arginine $\bullet$ aminoguanidine $\bullet$ transplantation $\bullet$ lung

\section{Introduction}

Despite recent advances in understanding chronic rejection, the regulatory and effector mechanisms underlying the disease process remain incompletely known (1). Observations in a heterotopic rat tracheal allograft model demonstrate that recruitment of CD4+ and CD8+ T cells and macrophages into airway wall induces local cytokine and growth factor production leading to epithelial damage, proliferation of smooth muscle cells, and gradual occlusion of airway lumen (2-4), i.e., histological changes similar to those observed in human lung allografts with obliterative bronchiolitis $(\mathrm{OB})^{1}(5)$.

Nitric oxide (NO) has a significant role in several physiological and pathological conditions such as vasorelaxation, neurotransmission, platelet and leukocyte adhesion, and host defense mechanisms against bacteria and viruses (6). NO is generated from L-arginine by the enzyme NO synthase (NOS) (7). NOS can be either constitutively expressed (cNOS) or induced by cytokines and LPS (iNOS) (7). cNOS has been localized in vascular endothelium (eNOS), platelets, and neurons (nNOS) of the central nervous system (7). cNOS produces small quantities of NO with activity regulated by intracellular calcium/calmodulin, and is involved in a variety of normal physiological functions. iNOS can produce large amounts of $\mathrm{NO}$, and is calcium-independent. iNOS is expressed in macrophages, vascular smooth muscle cells, endothelial cells, mesangial cells, and airway epithelium (7-9). In contrast to many other organs, NO is continuously produced by iNOS in normal airway epithelium, and regulates bronchomotor tone $(10,11)$. In addition, NO may regulate several inflammatory responses in the lung such as development of asthma and granulomatous inflammation (12-14).

During chronic rejection, there is a major release of proinflammatory molecules by infiltrating activated $\mathrm{T}$ cells and macrophages that participate in the immune reaction to foreign MHC and other antigens present in endothelial, epithelial, and other cells of the transplanted organ. Cytokines derived from activated macrophages, i.e., TNF- $\alpha$ and IL- $1 \beta$, and those derived from Th1 cells, i.e., IL- 2 and IFN- $\gamma$, promote iNOS expression (8). Recently induction of iNOS (15) and production of NO (16) during acute allograft rejection was demonstrated,

1. Abbreviations used in this paper: BrdU, bromodeoxyuridine; cNOS, constitutive nitric oxide synthase; eNOS, cNOS localized in the vascular endothelium; GAPDH, glyceraldehyde-3-phosphate dehydrogenase; iNOS, inducible nitric oxide synthase; nNOS, cNOS localized in neurons; NO, nitric oxide; OB, obliterative bronchiolitis; $\mathrm{RT}$, reverse transcriptase. 
and it was shown that treatment with aminoguanidine, a preferential inhibitor of iNOS (17), significantly attenuated pathogenesis of acute cardiac and lung allograft rejection $(18,19)$. This study was undertaken to investigate whether iNOS is induced during experimental $\mathrm{OB}$ in rat tracheal allografts, and to investigate the biological role of $\mathrm{NO}$ by supplementation of NO pathway by L-arginine, or by inhibition of the iNOS pathway by aminoguanidine in this model.

\section{Methods}

Heterotopic rat tracheal transplantation model and study design. Specific pathogen-free, 2-3-mo-old inbred male DA (AG-B4, RT1 ${ }^{\mathrm{a}}$ ) and WF (AG-B2, RT1 ${ }^{\mathrm{u}}$ ) rats weighing 200-300 g (Laboratory Animal Center, University of Helsinki, Helsinki, Finland) were used. Allogeneic heterotopic tracheal transplantations were performed as described $(3,4)$ from DA to WF rats, and syngeneic controls from DA to DA rats. Four groups were formed: $(a)$ nontreated syngeneic controls, $(b)$ nontreated allogeneic controls, $(c)$ allografts treated with aminoguanidine, a preferential inhibitor of iNOS (17), and (d) allografts supplemented with an NO precursor, L-arginine (7). The grafts were removed 3,10 , and $30 \mathrm{~d}$ after transplantation to determine histological changes, relative intragraft iNOS mRNA, protein expression, and nitrite/nitrate production. In addition, a detailed immunohistochemical analysis was performed to localize iNOS production and to examine how NO may modulate inflammatory cell infiltration and cytokine production in the airway wall of tracheal transplants.

Aminoguanidine and L-arginine administration. Aminoguanidinetreated allografts received aminoguanidine hemisulfate (Sigma Chemical Co., St. Louis, MO) by injection of $400 \mathrm{mg} / \mathrm{kg} / \mathrm{d}$ i.p. in three doses $(100 \mathrm{mg} / \mathrm{kg}$ at 9:00 AM, $100 \mathrm{mg} / \mathrm{kg}$ at 1:00 PM, and $200 \mathrm{mg} / \mathrm{kg}$ at 5:00 $\mathrm{PM}$ ) in $0.9 \% \mathrm{NaCl}$ in a concentration of $100 \mathrm{mg} / \mathrm{ml}$, previously shown to decrease serum NO concentrations to $30 \%$ of normal in rats (18). L-arginine (L-arginine hydroxychloride; Sigma Chemical Co.) was given orally at a concentration of $2.25 \%$ dissolved in tap water (available ad libidum), a solution previously shown to increase plasma L-arginine levels twofold (20).

Histological evaluation. The grafted trachea was excised, embedded in Tissue-Tek (Miles Inc., Elkhart, IN), snap-frozen in liquid nitrogen, and stored at $-70^{\circ} \mathrm{C}$ until used. For histological evaluation, frozen sections were stained with Mayer's hematoxylin-eosin. The histological changes in respiratory epithelium were evaluated as a percentage of normal respiratory, abnormal cuboidal and squamous epithelium, or loss of epithelium. Luminal occulusion was evaluated as a reduction of luminal area using an ocular grid. All the analyses were done in a blinded review by two observers, and the scores of these two observers were highly correlated $\left(r^{2}=0.95\right)$. The degree of airway wall inflammation, the cell types of the fibroproliferative lesion, and the number of proliferating inflammatory and myofibroproliferative cells were analyzed using immunohistochemistry.

Single immunostaining. Serial frozen sections $(4-6 \mu \mathrm{m})$ were airdried on silane-coated slides, fixed in acetone at $-20^{\circ} \mathrm{C}$ for $20 \mathrm{~min}$, and stored at $-20^{\circ} \mathrm{C}$ until used. Before immunostaining, the slides were refixed with chloroform and then air-dried. After incubation with appropriate $1.5 \%$ nonimmune serum (Vector Laboratories, Inc., Burlingame, CA) for mAbs or pAbs, frozen sections were incubated with a mouse $\mathrm{mAb}$ at room temperature for 30 to $60 \mathrm{~min}$, or with a rabbit or goat $\mathrm{pAb}$ at $+4^{\circ} \mathrm{C}$ for $12 \mathrm{~h}$. The primary Abs were diluted in PBS with $1 \%$ BSA and appropriate $3 \%$ nonimmune serum. With intervening washes in Tris-buffered saline, the slides were immersed in bionylated horse anti-mouse, goat anti-rabbit, or rabbit anti-goat rat-absorbed antibodies at room temperature for $30 \mathrm{~min}$ followed by avidin-bionylated horseradish complex (Vectastain Elite ABC Kit; Vector Laboratories) in PBS at room temperature for $30 \mathrm{~min}$. The reaction was revealed by chromogen 3-amino-9-ethylcarbazole (AEC; Sigma Chemical Co.) containing $0.1 \%$ hydrogen peroxidase, yielding a brown-red reaction product. The specimens were counterstained with hematoxylin and coverslips were aquamounted (Aquamount; BDH Chemicals Ltd., Poole, England).

Antibodies used. Details of the Abs and their use in immunohistology were described previously unless otherwise specified (3). Abs were directed against rat macrophages (ED1; Serotec Ltd., Oxford, United Kingdom), activated macrophages (ED3; Serotec Ltd.), CD4 (W3/25; Sera-Lab, Sussex, United Kingdom), and CD8 (OX8; Sera$\mathrm{Lab}$ ) subsets. Immune activaton was determined using mouse mAbs to MHC class II common determinant (OX6; Sera-Lab) and IL-2R (PharMingen, San Diego, CA); mouse mAbs to IFN- $\gamma$ (CY-047; Innogenetics, Zwijndrecht, Belgium), TNF- $\alpha$ (CY-051; Innogenetics), and IL-4 (MRC OX-81; Serotec Ltd.); rabbit pAbs to IL-1 $\alpha$ (IP-110) and IL-1 $\beta$ (LP-712; Genzyme Corp., Cambridge, MA); and goat IgG pAbs to IL-2 (SC-1786; Santa Cruz Biotechnology, Santa Cruz, CA) and IL-10 (AB-417-NA; R\&D Systems, Minneapolis, MN). NOS was localized using rabbit IgG pAbs to mouse and rat iNOS (NOS2, SC650; Santa Cruz Biotechnology) and cNOS (NOS3, SC-654; Santa Cruz Biotechnology).

Double immunostaining. To localize iNOS expression on macrophages, endothelial cells, and smooth muscle cells, double staining was applied on representative frozen sections. After staining for iNOS using the peroxidase ABC method described above (yielding a brown-red reaction product), tracheal segments were washed in Trisbuffered saline, and avidin-biotin complex from the first step was blocked by incubating the sections with an excess of avidin and biotin (Avidin/Biotin Blocking Kit; Vector Laboratories, Inc.). After application of antibodies to macrophages (ED1), endothelial cells (RECA 1; Serotec Ltd.), or $\alpha$-smooth muscle cell actin (1A4; Biomakor, Rehovot, Israel) at room temperature for $30 \mathrm{~min}$, sections were incubated with bionylated horse anti-mouse rat-absorbed antibodies at room temperature for $30 \mathrm{~min}$, followed by incubation with alkaline phosphatase avidin-biotin complex (Vectastain Elite ABC Kit; Vector Laboratories, Inc.) and visualized by Vector blue, an alkaline phosphate substrate kit (Vector Laboratories, Inc.) that produced a blue reaction. Double-stained sections were not counterstained.

Specificity controls of immunostaining. Controls were performed using the same immunoglobulin concentrations of species and isotype-matched antibodies: mouse monoclonal IgG1 antibody (catalog no. X931; Dako Corp., Carpinteria, CA) and rabbit polyclonal immunoglobulin fraction (catalog no. X936; Dako Corp.) for mAbs and pAbs, respectively. Additional specificity controls for iNOS, cNOS, TNF- $\alpha$, IL- $1 \alpha$, IL- $1 \beta$, and IFN- $\gamma$ stainings involved use of a working dilution of the polyclonal antibody after overnight incubation with a 10 to 20-molar excess of recombinant cytokine (Genzyme Corp.) or peptide (Santa Cruz Biotechnology). None of these control stainings showed any immunoreactivity.

Quantitation of immunohistochemistry. The immunohistochemical analysis was done in a blind review by two observers, and the score assigned was determined by consensus. The intensity of the staining was scored from 0 to 3 as follows: 0 , no visible staining; 1 , few cells with faint staining; 2 , moderate intensity with multifocal staining; and 3 , intense diffuse staining of the cells analyzed. Positive staining for IL was scored as the number of positive cells in cross-section.

In vivo labeling for cell proliferation. All recipients were injected with $400 \mu \mathrm{l}$ i.v. of a concentrated solution of bromodeoxyuridine (BrdU; Zymed Laboratories, Inc., San Francisco, CA) $3 \mathrm{~h}$ before death. Cell proliferation in frozen sections was revealed by an IgG1 mouse mAb to BrdU 1:20 (M744; Dako A/S, Glostrup, Denmark) and a Vectastain Elite ABC Kit (Vector Laboratories) method as described above. Before staining, the frozen sections were fixed with buffered formalin for $15 \mathrm{~min}$. After a 10-min wash in PBS, the sections were microwave-treated with $500 \mathrm{~W}$ in $0.1 \mathrm{M}$ citrate buffer, $\mathrm{pH}$ 6, for 5 min to break the double-stranded DNA, followed by a 10-min wash in PBS. Cell proliferation was measured by counting the number of labeled nuclei in tracheal cross-sections.

Reverse transcriptase (RT) PCR. Relative iNOS gene transcript levels were measured with semiquantitative RT-PCR after normal- 
ization against levels of the reference gene glyceraldehyde-3-phosphate dehydrogenase (GAPDH). Total RNA isolation was extracted from fresh trachea tissue using a guanidine-isothiocyanate preparation as descibed $(21,22)$. The total RNA yields were estimated by spectrophotometry, and were confirmed by $1 \%$ agarose/TBE gel electrophoresis.

To identify the optimum PCR conditions for accurate measurement of each gene, we established the logarithmic assay range with respect to cycle number and starting template concentration against different dilutions of cDNA. $1 \mu \mathrm{g}$ of total RNA was reverse-transcribed to cDNA in a $20-\mu l$ volume of master mix: $1 \times$ RT buffer (Promega Corp., Madison, WI), 300 mM dNTP (GeneAmp; Perkin-Elmer Corp., Norwalk, CT), 50 pmol oligo-dT primer ( $\mathrm{p}[\mathrm{dT}]_{15}$ primer; BoehringerMannheim, Mannheim, Germany), 20 U RNasin (RNasin Ribonuclease Inhibitor; Promega Corp.), and $100 \mathrm{U}$ reverse transcriptase (M-MLV-RTase Reverse Transcriptase, RNase H Minus; Promega Corp.) at $+37^{\circ} \mathrm{C}$ for $90 \mathrm{~min} .1 \mu \mathrm{l}$ of cDNA reaction mixture was added to $37.4 \mu \mathrm{l}$ of water and supplemented with $5 \mu \mathrm{l} 10 \times$ PCR buffer I (GeneAmp; Perkin Elmer Corp.), $10 \mathrm{nmol}$ dNTP (GeneAmp; Perkin Elmer Corp.), $\left.1 \mu \mathrm{Ci} \alpha{ }^{32} \mathrm{P}\right] \mathrm{dATP}, 3000 \mathrm{Ci} / \mathrm{mmol}$ (Amersham Intl., Buckinghamshire, England), 10 pmol iNOS sense primer (5'-CTT TGT GCG GAG TGT CAG TGG-3'[GenBank accession no. D12520]), 10 pmol iNOS antisense primer (5'-TTC TTC CTG ATA GAG GTG GTCC-3'), and 2.5 U AmpliTaq Gold (Perkin Elmer Corp.). The samples were heated to $95^{\circ} \mathrm{C}$ for $10 \mathrm{~min}$, and then cycled 37 times $\left(94^{\circ} \mathrm{C}\right.$ for $30 \mathrm{~s}, 60^{\circ} \mathrm{C}$ for $30 \mathrm{~s}, 72^{\circ} \mathrm{C}$ for $\left.1 \mathrm{~min}\right)$ using the 96 -well PCR apparatus (GenAmp PCR System 9600 apparatus; Perkin Elmer Corp.). The relative amount of GAPDH mRNA was analyzed by a similar protocol using GAPDH sense (5'-GTC TTC ACC ACC ATG GAG AAG GCT-3' [GenBank accession no. M17701]) and GAPDH antisense (5'-TGT AGC CCA GGA TGC CCT TTA GTG-3') primers. The PCR protocol for GAPDH was as follows: $95^{\circ} \mathrm{C}$ for $10 \mathrm{~min}$, and then amplification for 33 cycles $\left(94^{\circ} \mathrm{C}, 1 \mathrm{~min}\right.$, $57^{\circ} \mathrm{C}, 1 \mathrm{~min}, 72^{\circ} \mathrm{C}, 2 \mathrm{~min}$ ). Gene transcript levels for all samples for a single gene were amplified simultaneously, and each PCR analysis was completed in triplicate. For each experiment, the negative controls for which water was used instead of cDNA or reverse transcriptase was omitted during cDNA synthesis. The PCR samples were electrophoresed through $2 \%$ agarose. Subsequently, the gel was dried (LKB 2003 Slab Gel Dryer; LKB, Bromma, Sweden), exposed to an imaging plate (Fuji Photo Film Co., Tokyo, Japan), and the gels were quantified using a Fuji BAS1500 phosphoimager. The mean values of the three determinations were used for final analysis, and the normalized iNOS mRNA levels were derived by dividing the mean of iNOS mRNA with the mean of GAPDH mRNA for each tissue sample.

Spectrometric determination of intragraft nitrites and nitrates. Intragraft NO production was determined as stable metabolite nitrites and nitrates $\left(\mathrm{NO}_{\mathrm{x}}\right)$. Tracheas were snap-frozen and stored in $-70^{\circ} \mathrm{C}$. Homogenization was done in ultrapure water (MilliQ; Millipore Corp., Bedford, MA) with a Douche homogenizator at $+4^{\circ} \mathrm{C}$. The crude homogenate was centrifuged $(4000 \mathrm{~g})$. To prevent interference of proteins and hemegroups, the supernatant was filtrated through Centricon filters (Amicon Inc., Beverly, MA), exclusive size $10.000 \mathrm{D}$, and the rest of the proteins in the filtrate were precipitated in 1:20 of $20 \%$ $\mathrm{ZnSO}_{4}$. The supernatants were divided for two assays: one for measurement of $\mathrm{NO}_{2}{ }^{-}+\mathrm{NO}_{3}{ }^{-}$and for the measurement of $\mathrm{NO}_{2}{ }^{-} \cdot \mathrm{NO}_{2}{ }^{-}$ was measured with the Griess reaction, and nitrate reductase (EC 1.6.6.2, Aspergillus species; Boehringer Mannheim) was used to reduce the $\mathrm{NO}_{3}{ }^{-}$to $\mathrm{NO}_{2}{ }^{-}$used in the Griess reaction $(23,24)$. All determinations were performed in duplicate, and the results are given in $\mathrm{nmol} / \mathrm{mg}$ of tissue. The detection limit of the assay was $0.25 \mu \mathrm{M}$, and absorbance in $540 \mathrm{~nm}$ was measured.

Statistical analyses. All data are expressed as mean \pm SEM. For multiple group comparisons of small sample size nonparametric, Kruskal-Wallis (Statview 512+ program; Brain Power Inc., Calabasas, CA) one-way analysis by ranks was used. The rank sums obtained with the Kruskal-Wallis test were then used for the Dunn test at significance levels of 5 and 1\% (Medstat; Astra Group A/S, Copenhagen, Denmark). In groups with normal distribution and standard variance (F-test), one-factor ANOVA and Fisher PLSD-test were used at significance levels of 5 and $1 \% . P<0.05$ was regarded as statistically significant.

\section{Results}

Histology. The morphological changes of respiratory epithelium and the degree of luminal occlusion of tracheal grafts at different time points are summarized in Fig. $1.3 \mathrm{~d}$ after transplantation, the respiratory epithelium of syngeneic grafts was slightly damaged, probably due to ischemic injury before revascularization of the graft. $30 \mathrm{~d}$ after transplantation, the respiratory epithelium of syngeneic grafts was fully recovered,
A

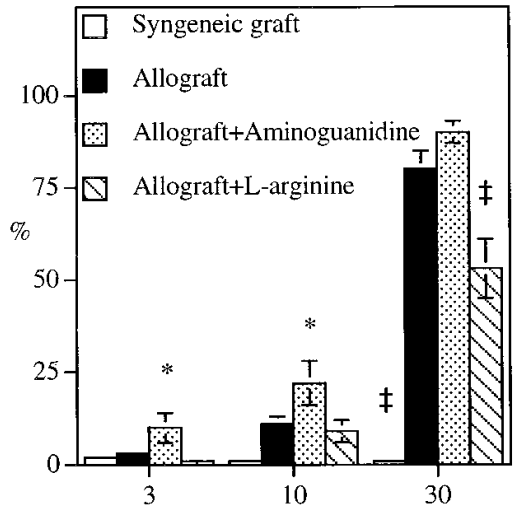

days after transplantation
B

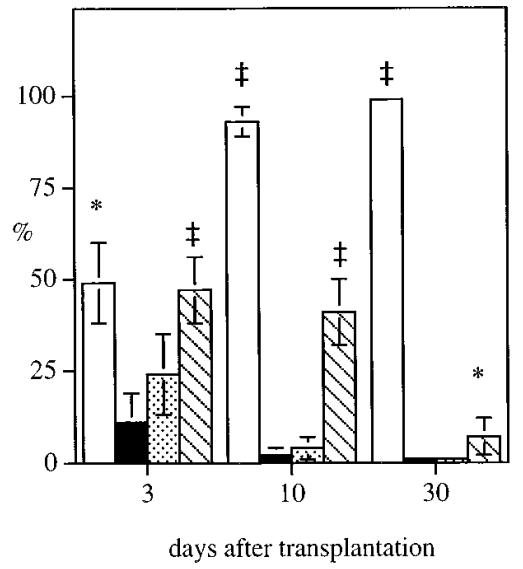

$\mathrm{C}$

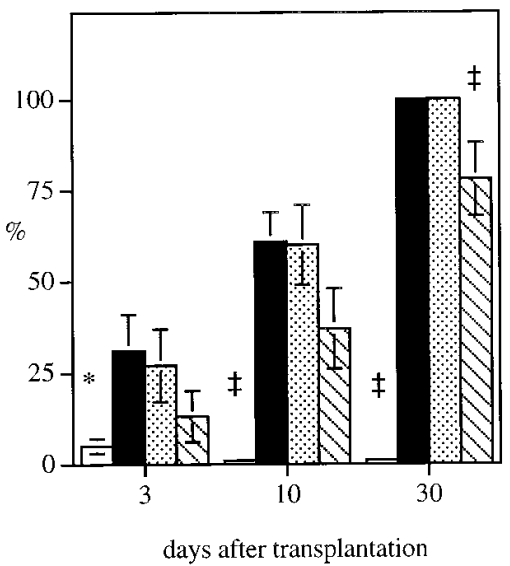

Figure 1. Histological features of syngeneic grafts, nontreated, aminoguanidine-treated, and L-arginine-treated allografts at various time points. $(A)$ The degree of luminal occlusion, $(B)$ percentage of airway lumen covered with normal respiratory epithelium, and $(C)$ percentage of epithelial necrosis. Data is expressed as mean \pm SEM. One-factor ANOVA and Fisher PLSD-test were used to evaluate significancies among the four groups. $* P<0.05, \stackrel{\ddagger}{\stackrel{P}{P}}<0.01$ when compared with nontreated allografts. 
A Syngeneic graft

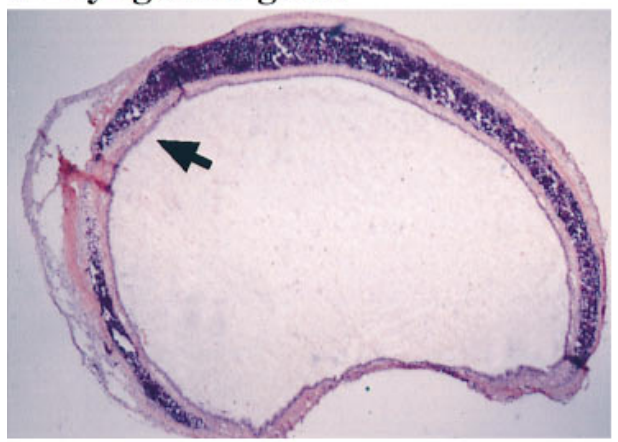

C Allograft+Aminoguanidine

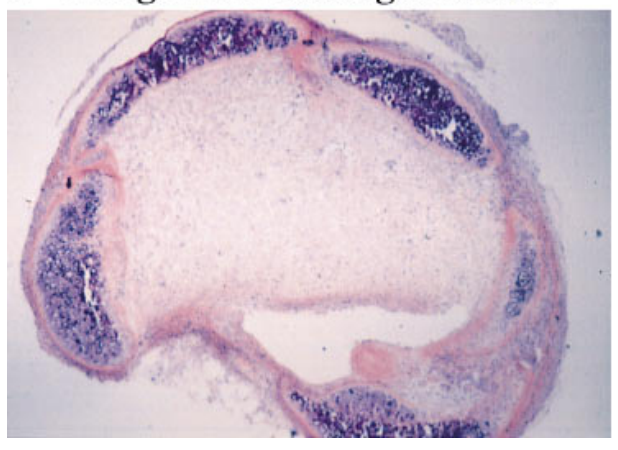

B Allograft

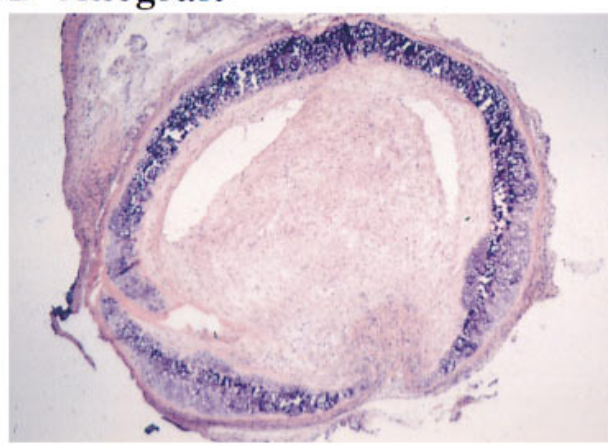

D Allograft+L-arginine

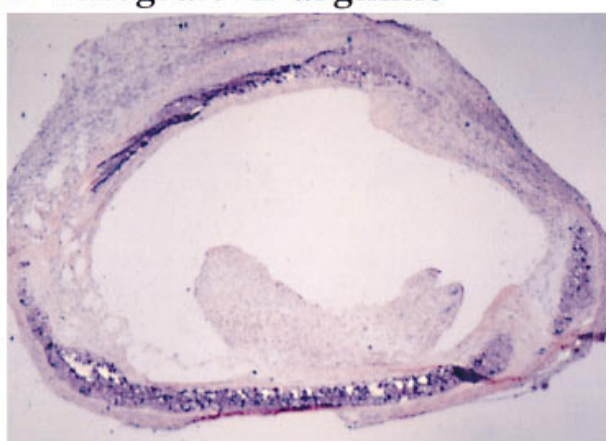

Figure 2. Photomicrographs of $(A)$ syngeneic graft, $(B)$ nontreated, $(C)$ aminoguanidine-treated, and $(D)$ L-arginine-treated allografts $30 \mathrm{~d}$ after transplantation. Syngeneic grafts were filled with mucus, and the airway was covered with normal respiratory epithelium (arrow). In nontreated and aminoguanidinetreated allografts, the airway lumen was severely compromised by dense myofibroproliferative lesions ( $B$ and $C)$. L-arginine treatment significantly ameliorated development of the obliterative lesion. Mayer's haematoxylin \& eosin staining, $40 \times$ original. and the grafts were filled with mucous, a sign of normal epithelium function. In syngeneic grafts, no myofibroproliferation occured, and overall histology resembled that of nontransplanted tracheas (Fig. $2 A$ ). In nontreated allografts, there was a progressive loss of respiratory epithelium. Airway wall inflammation peaked $10 \mathrm{~d}$ after transplantation, and subsided thereafter. In nontreated allografts, the luminal surface was reduced by myofibroproliferative lesion already at $10 \mathrm{~d}$, and at
$30 \mathrm{~d}$ intense myofibroproliferation nearly totally occluded the lumen (Fig. 2 B). Aminoguanidine treatment significantly accelerated myofibroproliferative lesion development, compromising the luminal area already at 3 and $10 \mathrm{~d}$ compared to nontreated allografts $(P<0.05)$. Thereafter, the difference leveled off as the tracheal lumen was nearly totally occluded in both groups at $30 \mathrm{~d}$ (Figs. 1 and $2 \mathrm{C}$ ). L-arginine treatment significantly delayed epithelial destruction, and significantly down-

Table I. Expression of iNOS in Normal Tracheas, Syngeneic Grafts, Nontreated, Aminoguanidine-, and L-arginine-treated Allografts

\begin{tabular}{|c|c|c|c|c|c|c|c|}
\hline $\begin{array}{l}\text { Days after } \\
\text { transplantation }\end{array}$ & Group & $n$ & Epithelial cells & $\begin{array}{c}\text { Myofibroproliferative } \\
\text { lesion }\end{array}$ & $\begin{array}{l}\text { Capillary endothelial } \\
\text { cells }\end{array}$ & $\begin{array}{c}\text { Mononuclear } \\
\text { inflammatory cells }\end{array}$ & $\begin{array}{l}\text { Smooth muscle } \\
\text { cells }\end{array}$ \\
\hline 0 & Normal DA trachea & 6 & $0.5 \pm 0$ & & $0 \pm 0$ & $0.2 \pm 0.1$ & $0.1 \pm 0.1$ \\
\hline \multirow[t]{4}{*}{3} & Syngeneic graft & 10 & $0.1 \pm 0.1$ & & $0.1 \pm 0.1$ & $0.3 \pm 0.1$ & $0.1 \pm 0.1$ \\
\hline & Allograft & 12 & $0.3 \pm 0.3$ & & 0 & $0.8 \pm 0.1$ & $0.1 \pm 0.1$ \\
\hline & Allograft + aminoguanidine & 12 & $1.1 \pm 0.2$ & & $0.7 \pm 0.1$ & $1.2 \pm 0.2$ & $0.5 \pm 0.2$ \\
\hline & Allograft + L-arginine & 12 & $1.0 \pm 0.1$ & & $1.4 \pm 0.1^{\ddagger}$ & $1.2 \pm 0.1$ & $0.9 \pm 0.1^{\ddagger}$ \\
\hline \multirow[t]{4}{*}{10} & Syngeneic graft & 10 & $2.2 \pm 0.3$ & & $0.9 \pm 0.2$ & $0.6 \pm 0.1 *$ & $0.5 \pm 0.1$ \\
\hline & Allograft & 10 & $1.3 \pm 0.3$ & & $0.8 \pm 0.1$ & $1.2 \pm 0.2$ & $0.6 \pm 0.1$ \\
\hline & Allograft + aminoguanidine & 15 & $1.0 \pm 0.2$ & & $0.4 \pm 0.1$ & $0.8 \pm 0.1$ & $0.1 \pm 0.0^{\ddagger}$ \\
\hline & Allograft + L-arginine & 15 & $1.9 \pm 0.3$ & & $0.9 \pm 0.2$ & $1.4 \pm 0.2$ & $0.5 \pm 0.1$ \\
\hline \multirow[t]{4}{*}{30} & Syngeneic graft & 10 & $0.6 \pm 0.2$ & & $0.8 \pm 0.2$ & $0.3 \pm 0.1$ & $0.8 \pm 0.1$ \\
\hline & Allograft & 14 & & $0.2 \pm 0.1$ & $0.6 \pm 0.1$ & $0.5 \pm 0.1$ & $0.4 \pm 0.1$ \\
\hline & Allograft + aminoguanidine & 14 & & $0.3 \pm 0.1$ & $0.9 \pm 0.1$ & $0.7 \pm 0.1$ & $0.6 \pm 0.1$ \\
\hline & Allograft + L-arginine & 12 & & $0.7 \pm 0.2$ & $0.9 \pm 0.2$ & $0.8 \pm 0.1$ & $0.6 \pm 0.1$ \\
\hline
\end{tabular}

In allogeneic groups (allograft, allograft $+\mathrm{L}$-arginine, and allograft + aminoguanidine) at 3 and $10 \mathrm{~d}$, only some of the grafts had preserved epithelium where iNOS expression could be scored. Myofibroproliferative lesion was scored only at $30 \mathrm{~d}$, as at earlier time-points it was not observed constantly for scoring. Values are given as mean \pm SEM. ${ }^{*} P<0.05$, and ${ }^{\ddagger} P<0.01$ when compared with nontreated allografts (Kruskal-Wallis and Dunn tests). 


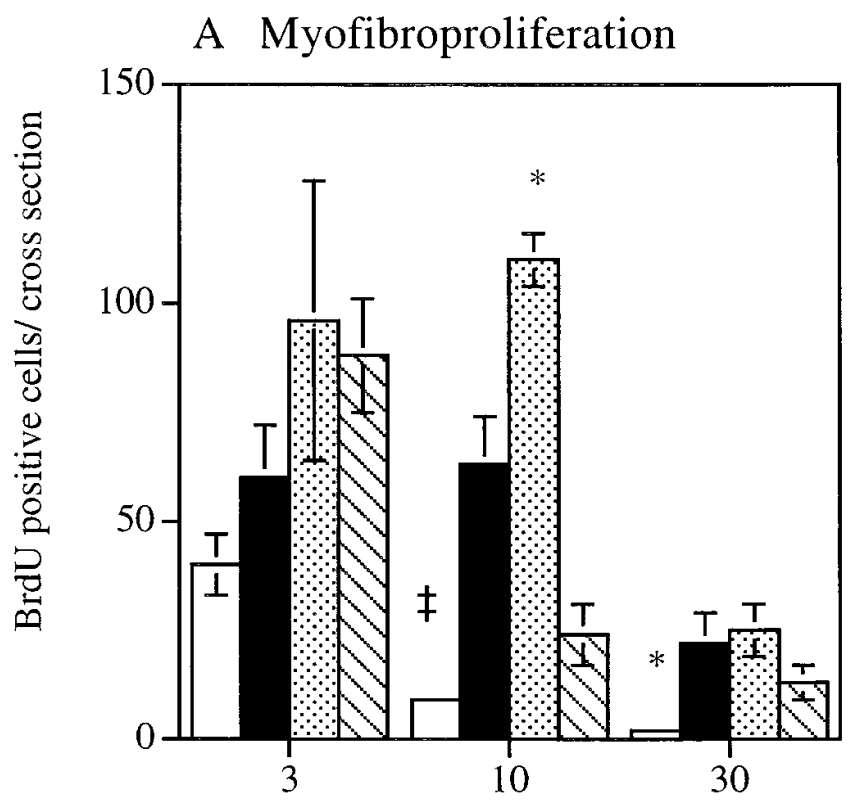

days after transplantation

\section{B Airway wall cell proliferation}

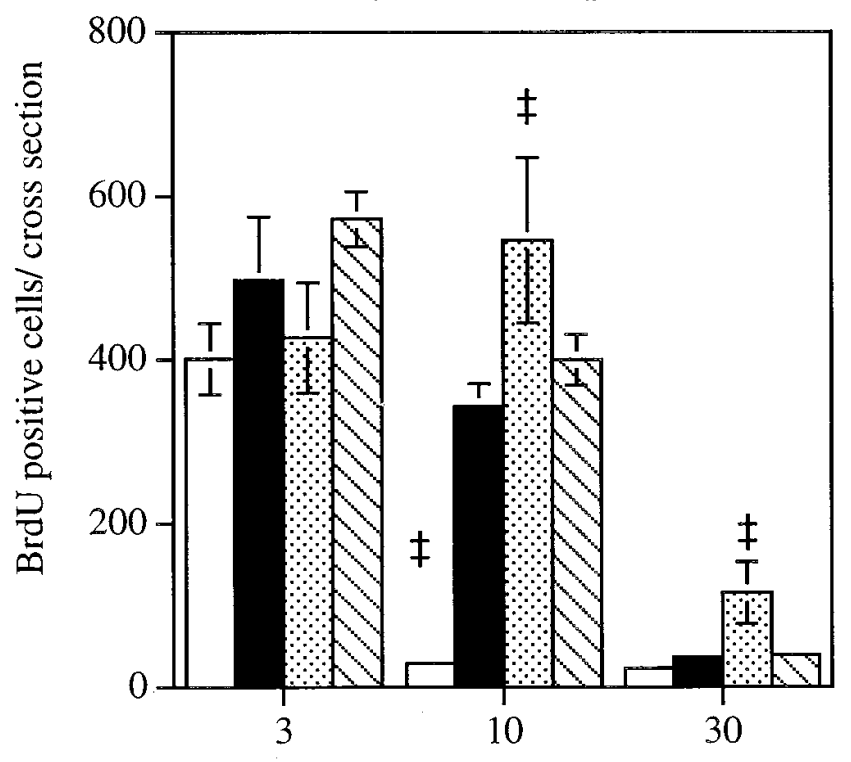

days after transplantation

Figure 3. Myofibroproliferation $(A)$ and airway wall cell proliferation $(B)$ in syngeneic grafts, nontreated, aminoguanidine-treated, and L-arginine-treated allografts at various time points. The number of BrdU-positive cells per cross section was counted. Data is expressed as mean \pm SEM. One-factor ANOVA and Fisher PLSD-test were used to evaluate significancies among the four groups. $* P<0.05$, ${ }^{\ddagger} P<0.01$ when compared with nontreated allografts. White bars, syngeneic graft; black bars, allograft; stippled bars, allograft + aminoguanidine; striped bars, allograft + L-arginine.

regulated the development of myofibroproliferative lesion at $30 \mathrm{~d}$ when compared to nontreated allografts $(P<0.01)$ (Figs. 1 and $2 D$ ).

In vivo cell proliferation. Cell proliferation in the airway wall and myofibroproliferative lesion of tracheal grafts was determined by BrdU immunoreactivity (Fig. 3). $3 \mathrm{~d}$ after transplantation, airway wall cell proliferation was prominent in both syngeneic grafts and allografts. In syngeneic grafts, the proliferative response ceased thereafter. In nontreated allografts, the airway wall cell proliferation peaked at $10 \mathrm{~d}$, whereas intense fibroproliferation continued up to $30 \mathrm{~d}$ resulting in total occlusion of the tracheal lumen as compared to syngeneic grafts. In aminoguanidine-treated allografts, the proliferation of airway wall cells, mainly smooth muscle cells and mononuclear inflammatory cells, was significantly enhanced at days 10 and 30 compared to other allogeneic groups. Aminoguanidine treatment was further associated with upregulation of fibroproliferation $10 \mathrm{~d}$ after transplantation, but not thereafter. L-arginine treatment reduced fibroproliferation at 10 and $30 \mathrm{~d}$ after transplantation, resulting in markedly diminished luminal occlusion, but had no effect on airway wall cell proliferation.

NOS protein expression. Immunohistochemistry and double stainings revealed iNOS expression in macrophages, smooth muscle cells, capillary endothelial cells, and epithelium (Fig. 4). Immunohistochemical analysis of normal nontransplanted tracheas localized weak iNOS expression in respiratory epithelium (Table I, Fig. $4 A$ ). In syngeneic grafts, induction of epithelial iNOS expression was observed at $10 \mathrm{~d}$, coinciding with recovery of respiratory epithelium of the grafts (Fig. $4 B$ ). In nontreated allografts, intensity of epithelial iNOS expression was downregulated compared to syngeneic grafts, reflecting ongoing damage of epithelial cells during the alloimmune response (Fig. $4 C$ ). Inflammatory cell iNOS expression was somewhat upregulated (Fig. 4 F). Aminoguanidine treatment did not affect the intensity of epithelial iNOS expression, but reduced the expression of capillary endothelial, ED1+ mononuclear inflammatory cell and smooth muscle cell $(P<0.01)$ iNOS expression at $10 \mathrm{~d}$ compared to nontreated allografts (Table I). L-arginine treatment significantly enhanced capillary endothelial and smooth muscle cell iNOS expression early after transplantation (Table I). In normal tracheas, weak cNOS expression was recorded in capillary endothelium, and in a few inflammatory cells. Neither transplantation, aminoguanidine, or L-arginine treatment had any effect on cNOS expression (data not shown).

Production of nitrites and nitrates. Spectrometric analysis and Griess-reaction were used to determine the intragaft NO production as nitrites and nitrates $\left(\mathrm{NO}_{\mathrm{x}}\right)$ (Table II). In a syngeneic group, intragraft $\mathrm{NO}_{\mathrm{x}}$ production was comparable to

Table II. Intragraft Nitric Oxide Production

\begin{tabular}{|c|c|c|c|c|c|c|}
\hline $\begin{array}{l}\text { Days after } \\
\text { transplantation }\end{array}$ & $n$ & $\begin{array}{l}\text { Normal DA } \\
\text { trachea }\end{array}$ & $\begin{array}{c}\text { Syngeneic } \\
\text { graft }\end{array}$ & Allograft & $\begin{array}{c}\text { Allograft }+ \\
\text { aminoguanidine }\end{array}$ & $\begin{array}{l}\text { Allograft }+ \\
\text { L-arginine }\end{array}$ \\
\hline 0 & 5 & $61 \pm 4$ & & & & \\
\hline 3 & 5 & & $61 \pm 2^{*}$ & $25 \pm 3$ & $32 \pm 6$ & $62 \pm 3^{*}$ \\
\hline 10 & 5 & & $90 \pm 18 *$ & $16 \pm 3$ & $38 \pm 6$ & $28 \pm 4$ \\
\hline 30 & 5 & & $64 \pm 28$ & $61 \pm 8$ & $68 \pm 5$ & $99 \pm 17$ \\
\hline
\end{tabular}

Intragraft nitric oxide production was measured as the total amount of nitrites and nitrates $\left(\mathrm{NO}_{2}{ }^{-}+\mathrm{NO}_{3}{ }^{-}\right.$, i.e. $\left.\mathrm{NO}_{\mathrm{x}}\right)$ at different time points after transplantation, and the results are given as $\mathrm{nmol} / \mathrm{mg}$ tissue (mean \pm SEM). $* P<0.05$, when compared nontreated allografts (nonparametric Kruskal-Wallis and Dunn tests). 
A Normal trachea

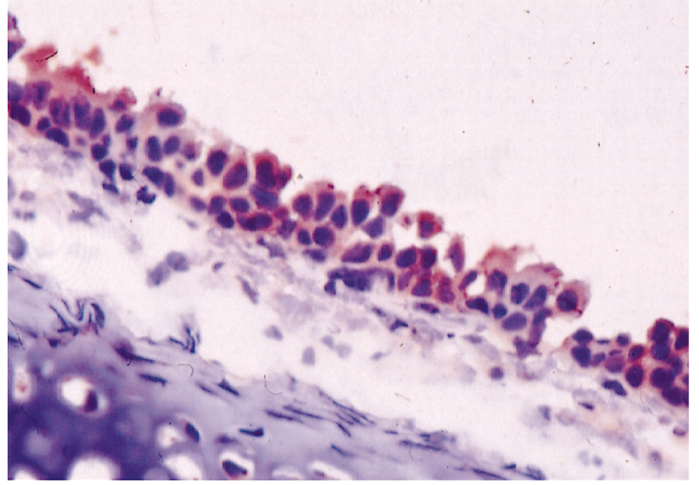

C Allograft

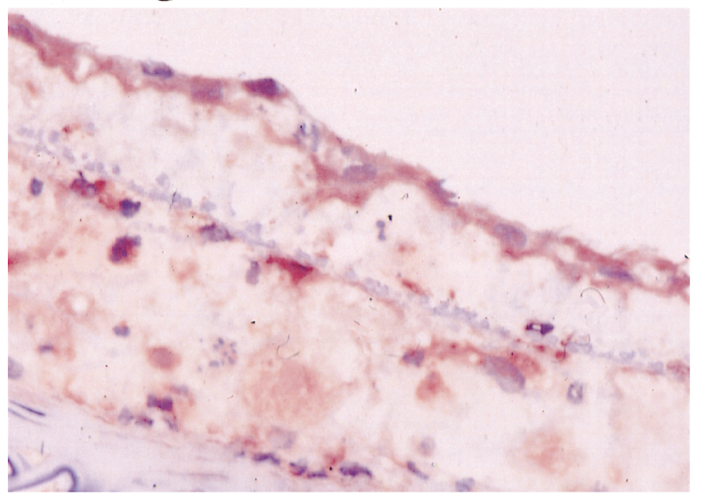

\section{E Allograft+L-arginine}

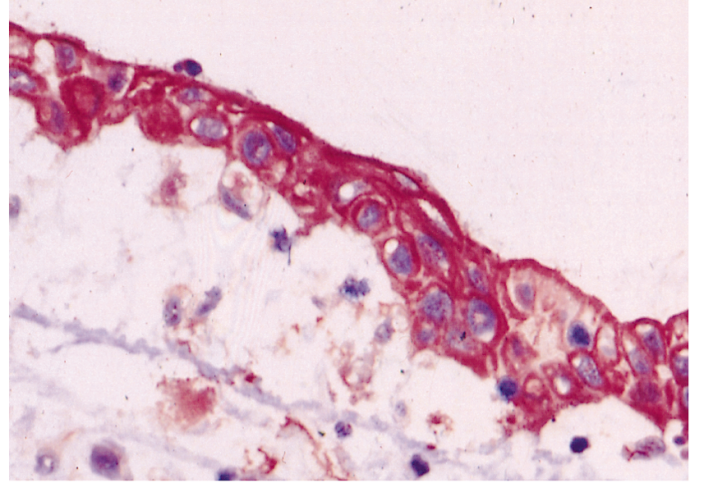

\section{G $\alpha$-actin+iNOS}

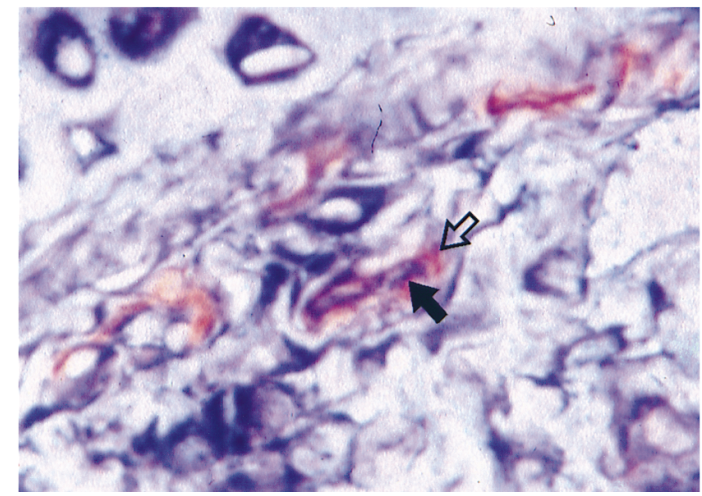

\section{B Syngeneic graft}

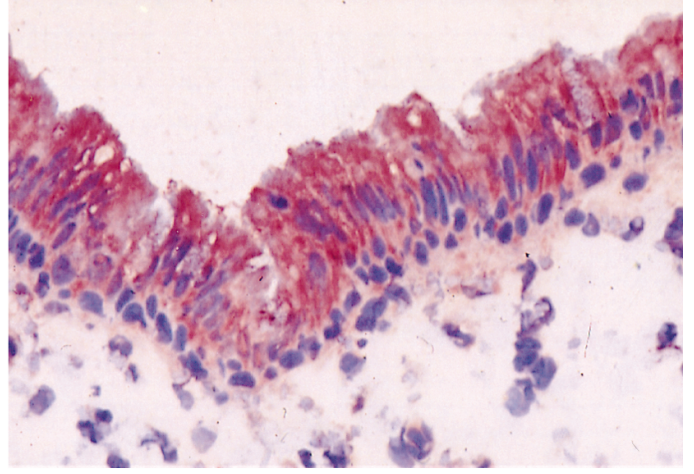

\section{Allograft+Aminoguanidine}

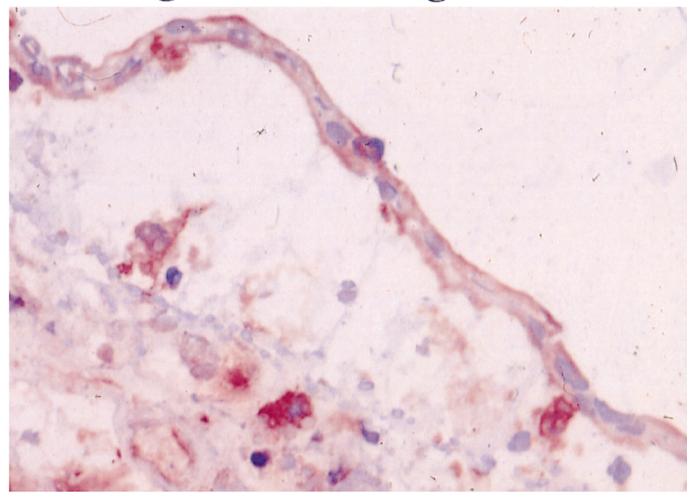

F ED1+iNOS

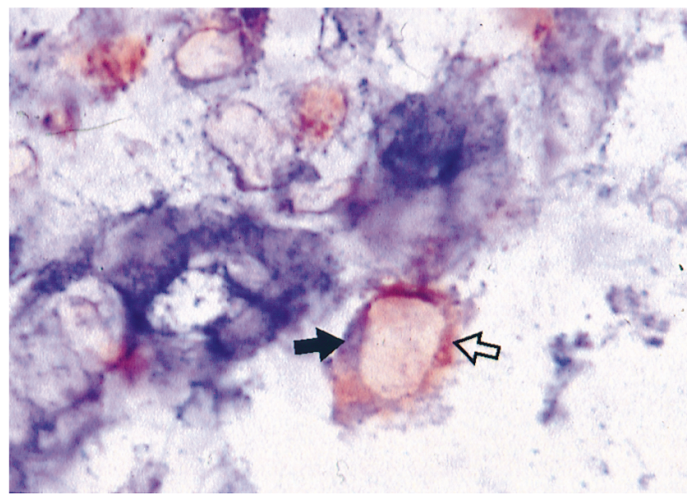

\section{H RECA+iNOS}

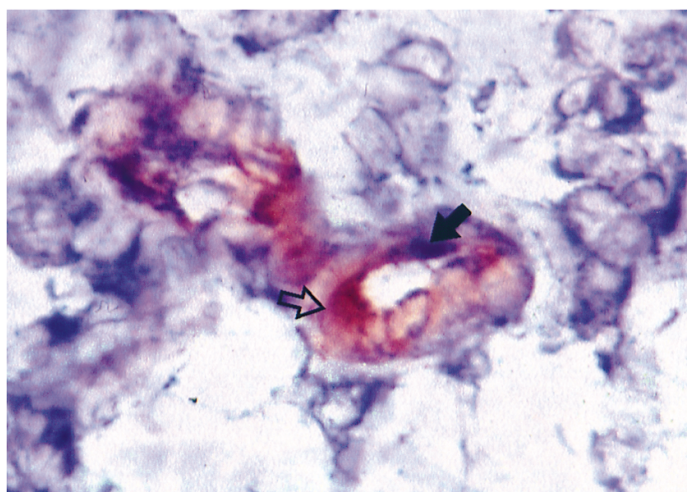

Figure 4. Photomicrographs of iNOS immunoreactivity in the epithelium of $(A)$ normal trachea, $(B)$ syngeneic graft, $(C)$ nontreated, $(D)$ aminoguanidine-treated, and $(E)$ L-arginine-treated allografts $10 \mathrm{~d}$ after transplantation $(400 \times$ original). Double stainings for $(F)$ ED1, $(G)$ $\alpha$-smooth muscle cell actin, and $(H)$ RECA in allografts $10 \mathrm{~d}$ after transplantation, revealed iNOS staining in macrophages, smooth muscle cells, and capillary endothelial cells, respectively. Open arrow (red), iNOS; filled arrow (blue), cell subsets (1000× original). 
Table III. Intragraft iNOS mRNA Expression

\begin{tabular}{rlcccc}
\hline $\begin{array}{l}\text { Days after } \\
\text { transplantation }\end{array}$ & $n$ & $\begin{array}{c}\text { Normal DA } \\
\text { trachea }\end{array}$ & $\begin{array}{c}\text { Syngeneic } \\
\text { graft }\end{array}$ & Allograft & $\begin{array}{c}\text { Allograft }+ \\
\text { aminoguanidine }\end{array}$ \\
\hline 0 & 6 & $0.05 \pm 0.03$ & & & $\begin{array}{c}\text { Allograft }+ \\
\text { L-arginine }\end{array}$ \\
3 & 6 & & $0.16 \pm 0.03$ & $0.24 \pm 0.03$ & $0.27 \pm 0.03$ \\
10 & 6 & $0.09 \pm 0.02^{*}$ & $0.34 \pm 0.03$ & $0.41 \pm 0.02$ \\
30 & 6 & $0.06 \pm 0.01$ & $0.05 \pm 0.02$ & $0.24 \pm 0.05^{*}$ \\
\hline
\end{tabular}

Relative iNOS gene expression levels were measured with semiquantitative RT-PCR after normalization against levels of reference gene GAPDH. Values are given as mean \pm SEM. $* P<0.05$ when compared with nontreated allografts (Kruskall-Wallis and Dunn tests).

that of nontransplanted tracheas. In nontreated allografts, $\mathrm{NO}_{\mathrm{x}}$ production was significantly downregulated at 3 and $10 \mathrm{~d}$ when compared with syngeneic controls. Aminoguanidine treatment did not further suppress $\mathrm{NO}_{\mathrm{x}}$ production, whereas L-arginine treatment significantly enhanced intragraft $\mathrm{NO}_{x}$ production early after transplantation.

iNOS mRNA expression. Semiquantitative RT-PCR was used to measure relative iNOS mRNA levels after normalization against levels of the reference gene GAPDH mRNA. In syngeneic grafts, induction of iNOS mRNA synthesis was seen at $3 \mathrm{~d}$ returning to the level of nontransplanted tracheas (Table III, Fig. 5). In nontreated allografts compared with syngeneic grafts, a significant induction of iNOS mRNA was observed at $10 \mathrm{~d}$, coinciding with the peak inflammatory response. Aminoguanidine treatment did not reduce iNOS mRNA levels but instead was associated with significant upregulation of iNOS mRNA at $30 \mathrm{~d}$, indicating that the inhibition of NO production may inhibit negative feedback of NO to iNOS mRNA synthesis (6). Supplementation of iNOS pathway with L-arginine increased iNOS mRNA expression at all time points compared with nontreated allografts.

Airway wall inflammation and intragraft cytokine expression of tracheal transplants. In nontreated allografts, a prominent airway wall infiltration of ED1+ and ED3 + macrophages, $\mathrm{CD} 4+$, and CD8+ $\mathrm{T}$ cells was observed at 3 and $10 \mathrm{~d}$ after

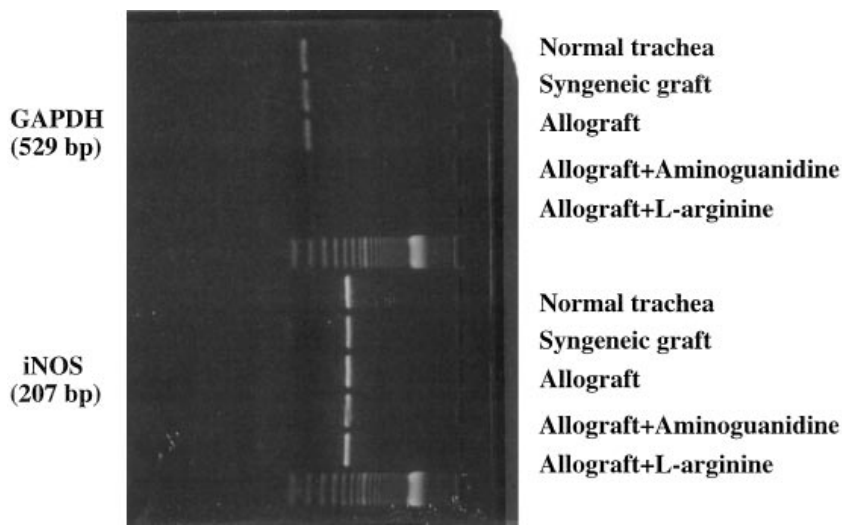

Figure 5. Example of RT-PCR of iNOS mRNA and GAPDH mRNA transcript levels from representative analyses that included one cDNA sample from each group, i.e., normal trachea, syngeneic graft, nontreated, aminoguanidine-treated and L-arginine-treated allografts $10 \mathrm{~d}$ after transplantation. The actual determinations were performed simultaneusly using the 96-well PCR apparatus, and were completed in triplicate. transplantation, subsiding thereafter. Many of the infiltrating inflammatory cells showed immune activation with expression of IL-2R and MHC class II. Also, strong epithelial MHC class II expression was recorded. Aminoguanidine or L-arginine treatment did not alter the intensity of airway wall inflammation or the immune activation of inflammatory cells. Allograft expression of proinflammatory cytokines, especially of TNF- $\alpha$, IFN- $\gamma$, IL-1, and IL-2 was upregulated compared to syngeneic grafts (Table IV, Fig. 6). Aminoguanidine treatment did not significantly alter allograft cytokine expression profiles. L-arginine treatment, however, was associated with upregulation of Th2 cytokines, IL-4, and IL-10 in the airway wall during peak inflammation at $10 \mathrm{~d}$ (Table IV, Fig. 6).

\section{Discussion}

Recent experimental observations in rodents demonstrate that heterotopic tracheal allografts develop myofibroproliferative lesions similar to those seen in small and large airways of human lung allografts with OB $(2-4,25,26)$. At the early phase of $\mathrm{OB}$ in heterotopic rat tracheal allografts, the respiratory epithelium strongly expresses MHC class II, enabling a direct presentation of foreign antigens to alloreactive T cells (4). In addition, graft-infiltrating recipient-derived professional APC such as dendritic cells and macrophages may process donor alloantigens for indirect $\mathrm{T}$ and $\mathrm{B}$ cell activation, leading to clonal cell proliferation and $\mathrm{Ab}$ production, respectively $(4,27)$. Recruitment of CD4+ and CD8+ T cells and macrophages into the airway wall induces local cytokine and growth factor production leading to epithelial damage, proliferation of $\alpha$-smooth muscle actin immunoreactive cells, and gradual occlusion of the airway lumen. In syngeneic grafts and allografts immunosuppressed with sufficient doses of cyclosporin A, obliterative changes do not develop, indicating the key role of alloimmune response in this disease process $(2,4,28)$.

$\mathrm{NO}$ is reported to be an important mediator of inflammatory responses in lungs (11). Recently, induction of NO producing enzyme iNOS and production of NO during rejection were demonstrated. It has also been shown that treatment with aminoguanidine, a preferential inhibitor of iNOS, significantly attenuated the pathogenesis of acute cardiac and lung allograft rejection $(15,16,18,19)$. Supplementation of NO in cardiac allograft ischemia-reperfusion injury prolonged graft survival, which may be due to the protective role of NO to endothelial cells $(29,30)$.

Although induction of iNOS mRNA and protein expression have been demonstrated in chronic rejection and allograft arteriosclerosis $(31,32)$, the biological role of NO in this dis- 


\begin{tabular}{|c|c|c|c|c|c|c|c|c|}
\hline $\mathrm{Ab}$ & \multicolumn{2}{|c|}{ Syngeneic graft } & \multicolumn{2}{|r|}{ Allograft } & \multicolumn{2}{|c|}{ Allograft + aminoguanidine } & \multicolumn{2}{|c|}{ Allograft + L-arginine } \\
\hline \multicolumn{9}{|c|}{ Inflammatory cells } \\
\hline ED1 & $0.5 \pm 0.1 *$ & MNC & $1.1 \pm 0.1$ & $\mathrm{MNC}$ & $1.1 \pm 0.1$ & $\mathrm{MNC}$ & $1.2 \pm 0.2$ & $\mathrm{MNC}$ \\
\hline ED3 & $0.5 \pm 0.1$ & & $0.7 \pm 0.1$ & $\begin{array}{l}\text { Myofibroproliferative } \\
\text { lesion, MNC }\end{array}$ & $0.5 \pm 0.1$ & $\begin{array}{l}\text { Myofibroproliferative } \\
\text { lesion, MNC }\end{array}$ & $0.7 \pm 0.2$ & $\begin{array}{l}\text { Myofibroproliferative } \\
\text { lesion, MNC }\end{array}$ \\
\hline $\mathrm{CD} 4$ & $0.5 \pm 0.2$ & MNC & $0.8 \pm 0.2$ & $\mathrm{MNC}$ & $1.1 \pm 0.1$ & $\mathrm{MNC}$ & $0.7 \pm 0.1$ & $\mathrm{MNC}$ \\
\hline CD8 & $0.2 \pm 0.1$ & $\mathrm{MNC}$ & $0.9 \pm 0.2$ & MNC & $1.2 \pm 0.3$ & $\mathrm{MNC}$ & $0.8 \pm 0.3$ & $\mathrm{MNC}$ \\
\hline \multicolumn{9}{|c|}{ Immune activation } \\
\hline MHC class II & $0.6 \pm 0.1 *$ & EP & $1.3 \pm 0.1$ & $\mathrm{EP}, \mathrm{MNC}$ & $1.4 \pm 0.1$ & $\mathrm{EP}, \mathrm{MNC}$ & $1.5 \pm 0.1$ & $\mathrm{EP}, \mathrm{MNC}$ \\
\hline IL-2R & $0 \pm 0 *$ & & $1.0 \pm 0.1$ & $\mathrm{EP}, \mathrm{MNC}$ & $1.3 \pm 0.2$ & $\mathrm{EP}, \mathrm{MNC}$ & $0.8 \pm 0.1$ & $\mathrm{EP}, \mathrm{MNC}$ \\
\hline \multicolumn{9}{|l|}{ Cytokines } \\
\hline IL-1 $\alpha$ & $0 \pm 0 *$ & & $0.6 \pm 0.1$ & $\mathrm{MNC}$ & $0.4 \pm 0.2$ & $\mathrm{MNC}$ & $0.6 \pm 0.1$ & MNC, SMC \\
\hline IL-1 $\beta$ & $0 \pm 0^{*}$ & & $0.3 \pm 0.1$ & $\mathrm{MNC}$ & $0.5 \pm 0.1$ & MNC & $0.2 \pm 0.0$ & $\mathrm{MNC}$ \\
\hline TNF- $\alpha$ & $0 \pm 0$ & & $0.3 \pm 0.1$ & MNC, SMC & $0.1 \pm 0.1$ & MNC, SMC & $0.3 \pm 0.1$ & MNC, SMC \\
\hline IFN- $\gamma$ & $0 \pm 0 *$ & & $0.9 \pm 0.2$ & $\mathrm{MNC}$ & $0.3 \pm 0.3$ & $\mathrm{MNC}$ & $1.3 \pm 1.3$ & $\mathrm{MNC}$ \\
\hline IL-2 & $0 \pm 0 *$ & & $172 \pm 48$ & $\mathrm{MNC}$ & $142 \pm 45$ & Airway wall MNC & $184 \pm 52$ & $\mathrm{MNC}$ \\
\hline IL-4 & $0 \pm 0$ & & $5 \pm 2$ & $\begin{array}{c}\text { Myofibroproliferative } \\
\text { lesion, MNC, SMC }\end{array}$ & $1 \pm 1$ & $\begin{array}{c}\text { Myofibroproliferative } \\
\text { lesion, MNC, SMC }\end{array}$ & $16 \pm 5$ & $\begin{array}{c}\text { Myofibroproliferative } \\
\text { lesion, MNC, SMC }\end{array}$ \\
\hline IL-10 & $0 \pm 0$ & & $3 \pm 1$ & $\mathrm{MNC}$ & $3 \pm 1$ & $\mathrm{MNC}$ & $48 \pm 28^{*}$ & $\mathrm{MNC}$ \\
\hline
\end{tabular}

Graft-infiltrating inflammatory cell subsets, immune activation, and expression of inflammatory cytokines in the grafts. EC, capillary endothelial cells; EP, epithelial cells; MNC, mononuclear inflammatory cells; SMC, smooth muscle cells. For IL-2, IL-4 and IL-10 the number of positive cells were scored per cross-section. For others, the intensity of staining was scored from 0 to 3 . Values are mean \pm SEM. $* P<0.05$, when compared with nontreated allografts (Kruskal-Wallis and Dunn tests).

ease process remains unknown. In models of ordinary atherosclerosis, inhibition of NOS has been shown to accelerate atherogenesis (33) and to increase cardiac fibrosis (34), whereas supplementation of NOS pathway with L-arginine reduced hypercholesterolemia and endothelial denudation-induced atherosclerosis $(20,35)$. The same beneficial effect with L-arginine, however, was not achieved in a chronic rejection model of femoral artery allografts in the rat (36).

In this communication we demonstrate a protective regulatory role of $\mathrm{NO}$ in $\mathrm{OB}$ development, i.e., chronic rejection. Supplementation of NO pathway by L-arginine resulted in significant reduction in the proliferation of $\alpha$-smooth muscle actin immunoreactive cells, and thereby in downregulation of tracheal allograft occlusion. L-arginine treatment also reduced epithelial damage and necrosis. In contrast, inhibition of iNOS by aminoguanidine treatment significantly accelerated development of $\mathrm{OB}$, particularly early after transplantation.

In normal tracheas and syngeneic grafts, iNOS was localized in the epithelium, suggesting that it may be the main source of NO. This result is consistent with an earlier report demonstrating continuous NO production by epithelial iNOS (10, 11). In nontreated allografts, an increase in the relative intragraft iNOS mRNA and mononuclear inflammatory cell iNOS immunoreactivity was demonstrated during progressive loss of respiratory epithelium and airway occlusion. The intragraft NO production was, however, decreased, possibly due to alloimmune damage to the epithelium, and thus decreased epi- thelial iNOS. The aminoguanidine treatment-enhanced OB was not associated with reduction of relative iNOS mRNA synthesis, but was linked to upregulation of relative iNOS mRNA at the end-point, indicating that inhibition of NO production may inhibit negative feedback of NO to iNOS mRNA synthesis (6). Aminoguanidine did not affect total intragraft NO production, but decreased iNOS immunoreactivity in smooth muscle cells. In contrast, the antiproliferative effect of L-arginine supplementation was linked with enhanced relative intragraft iNOS mRNA synthesis, iNOS immunoreactivity in capillary endothelial and smooth muscle cells, and intragraft NO production. L-arginine treatment, however, did not affect the number of macrophages, known to be an important source of iNOS (37).

Our findings suggest that one of the possible mechanisms of NO in OB prevention may be mediated by smooth muscle cell proliferation inhibition or enhanced revascularization of grafts by better-preserved capillary endothelium (30), indicated by increased iNOS expression in smooth muscle cells and capillary endothelium during L-arginine treatment. On the growth factor level of smooth muscle cell proliferation, NO inhibits platelet-derived growth factor (PDGF) expression (38), which is a major mitogen for smooth muscle cells, and may have an essential role in OB development $(3,39,40)$. NO also appears to inhibit smooth muscle proliferation directly through elevation of cyclic-GMP levels $(41,42)$.

Several mechanisms exist whereby NO may modulate immune responses in the graft. Supplementation of L-arginine has

Figure 6. Photomicrographs of cytokine stainings of syngeneic grafts, nontreated, aminoguanidine-treated, and L-arginine-treated allografts. Nontreated allografts expressed pro-inflammatory cytokines IL- $1 \alpha$, IL-1 $\beta$, TNF- $\alpha$, IFN- $\gamma$, and IL-2 when compared with syngeneic grafts. Aminoguanidine treatment did not significantly alter allograft cytokine expression profiles, while L-arginine treatment was associated with significant upregulation of Th2 cytokines, IL-4, and IL-10 in the airway wall during peak inflammation $10 \mathrm{~d}$ after transplantation. 


\section{Syngeneic graft Allograft}
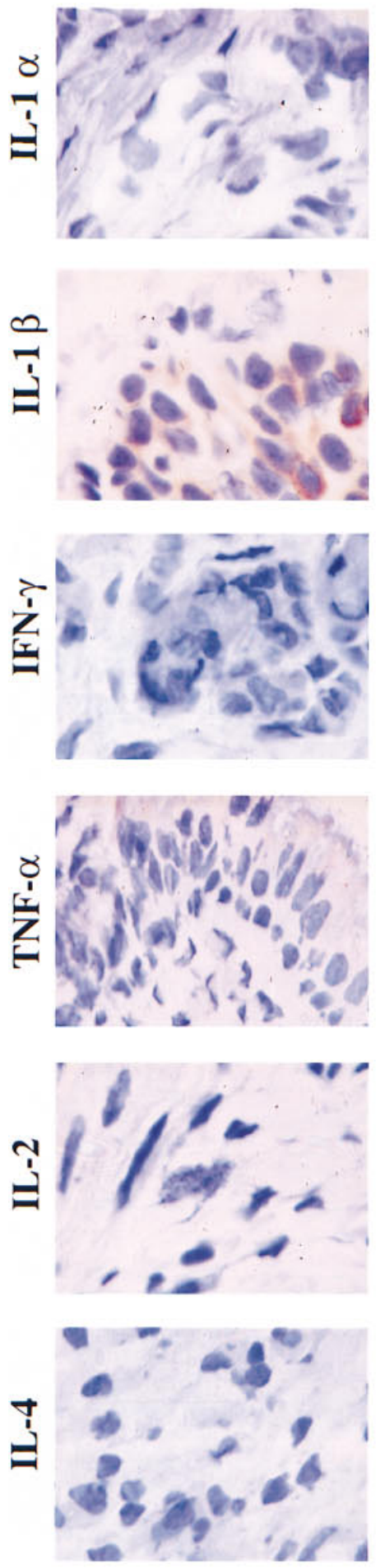

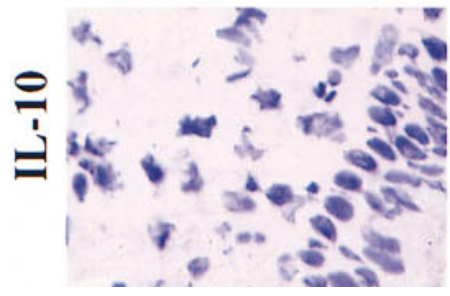
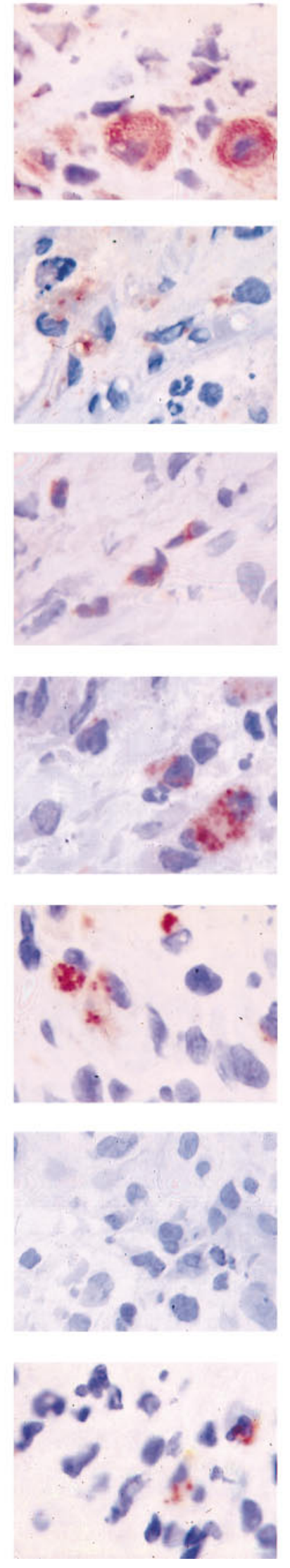

Allograft+

Aminoguanidine
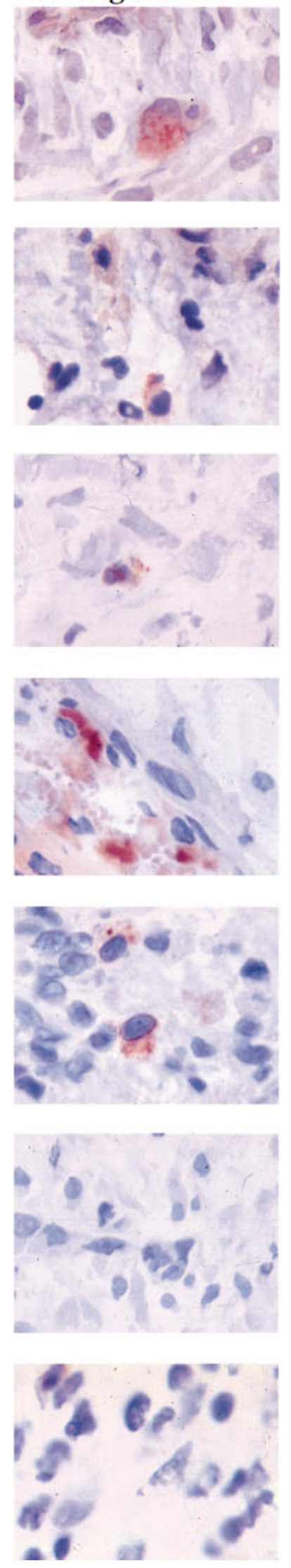

Allograft+

L-arginine
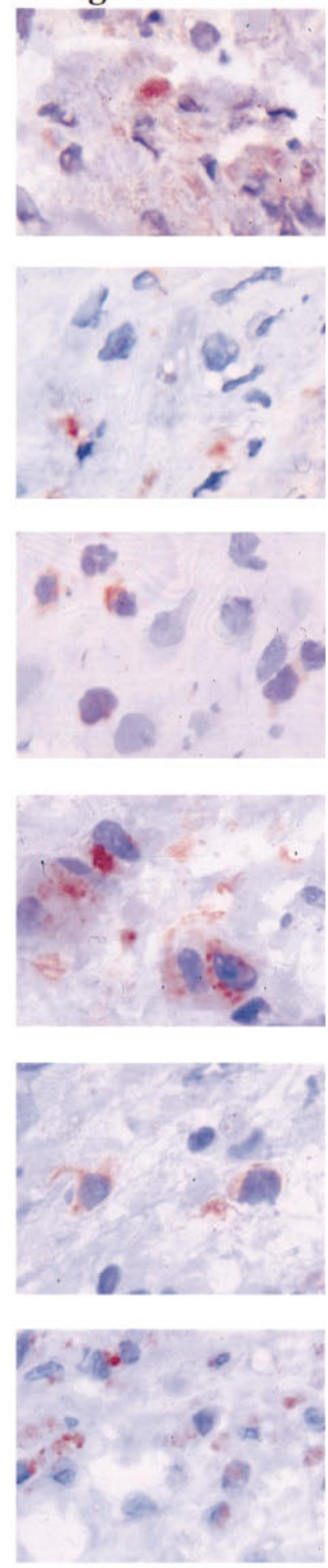

- 8 89 ix 
been shown to reduce platelet aggregation $(43,44)$ and leukocyte adhesion and emigration (45). In this study, supplementation of NO pathway or inhibition of iNOS pathway had no effect on the number of graft-infiltrating CD4+ or CD8+ T cells or macrophages, or on the level of immune activation with expression of IL-2R or MHC class II. Supplementation of NO pathway by L-arginine, however, modulated the immune response towards Th 2 cytokine IL- 4 and IL-10 production, which has been linked with prolonged graft survival and tolerance induction (46). NO has been shown to inhibit the expansion of cloned Th1, but not Th2 cells (47). Furthermore, observations in iNOS-deficient mice demonstrate that a low concentration of endogenously generated NO by cNOS may be required for Th1 cell proliferation, but a high concentration of NO produced by iNOS is necessary for prevention of potential overexpansion of Th1 cells, which is implicated in a variety of autoimmune diseases (48).

In conclusion, we demonstrate that $\mathrm{NO}$ has a protective role in the OB development: while NO pathway supplementation by L-arginine attenuated obliterative changes, preferential inhibitor of iNOS pathway enhances these changes. Our results indicate furthermore that potential mechanisms of NO in the prevention of OB include either inhibition of smooth muscle cell proliferation or altered immune response towards Th2 cytokines.

\section{Acknowledgments}

The authors wish to acknowledge the excellent technical assistance of E. Aaltola, R.N., M. Anttila, R.N., and E. Wasenius, R.N.

This study was supported by the Jalmari and Rauha Ahokas Foundation, the Finnish Medical Society Duodecim, the Helsinki University Central Hospital Research Funds, Helsinki, the Leiras Research Foundation, and the Farmos Pharmaceuticals, Turku, Finland.

\section{References}

1. Lemström, K., P. Koskinen, and P. Häyry. 1995. Molecular mechanisms of chronic renal allograft rejection. Kidney. Int. 48:S2-S10.

2. Morris, R.E., X. Huang, C.R. Gregory, M.E. Billingham, R. Rowan, R. Shorthouse, and G.J. Berry. 1995. Studies in experimental models of chronic rejection: use of rapamycin (sirolimus) and isoxazole derivates (Leflunomide and its analogue) for suppression of graft vascular disease and obliterative bronchiolitis. Transplant. Proc. 27:2068-2069.

3. Koskinen, P.K., E.A. Kallio, C.A. Bruggeman, and K.B. Lemström. 1997. Cytomegalovirus infection enhances experimental obliterative bronchiolitis in rat tracheal allografts. Am. J. Respir. Crit. Care Med. 155:2078-2088.

4. Koskinen, P.K., E.A. Kallio, R. Krebs, and K.B. Lemström. 1997. A dose-dependent inhibitory effect of cyclosporine A on obliterative bronchiolitis of rat tracheal allografts. Am. J. Respir. Crit. Care Med. 155:303-312.

5. Yousem, S.A., J.B. Berry, P.T. Cagle, D. Chamberlain, A.N. Husain, H.R. Hruban, A. Marchevsky, N.P. Ohori, J. Ritter, S. Stewart, and H.D. Tazelaar. 1996. Revision of the 1990 working formulation for the classification of pulmonary allograft rejection: lung rejection study group. J. Heart Lung Transplant. 15:1-15.

6. Moncada, S., and A. Higgs. 1993. The L-arginine-nitric oxide pathway. $N$. Engl. J. Med. 329:2002-2012.

7. Sessa, W.C. 1994. The nitric oxide synthase family of proteins. J. Vasc. Res. 31:131-143.

8. Nathan, C. 1992. Nitric oxide as a secretory product of mammalian cells. FASEB (Fed. Am. Soc. Exp. Biol.) J. 6:3051-3064.

9. Moncada, S., and E.A. Higgs. 1995. Molecular mechanisms and therapeutic strategies related to nitric oxide. FASEB (Fed. Am. Soc. Exp. Biol.) J. 9: 1319-1330.

10. Guo, F.H., H.R. De Raeve, T.W. Rice, D.J. Stuehr, F.B.J.M. Thunnissen, and S.C. Erzurum. 1995. Continuous nitric oxide synthesis by inducible nitric oxide synthase in normal human airway epithelium in vivo. Proc. Natl. Acad. Sci. USA. 92:7809-7813.

11. Barnes, P.J. 1995. Nitric oxide and airway disease. Ann. Med. 27:389-393.

12. Yan, Z.-Q., G.K. Hansson, B.-E. Skoogh, and J.O. Lötvall. 1995. Induc- tion of nitric oxide synthase in a model of allergic occupational asthma. Allergy (cph). 50:760-764.

13. Tsuji, M., V.B. Dimov, and T. Yoshida. 1995. In vivo expression of monokine and inducible nitric oxide synthase in experimentally induced pulmonary granulomatous inflammation. Am. J. Pathol. 147:1001-1015.

14. Hamid, Q., D.R. Springall, V. Riveros-Moreno, P. Chanez, P. Howarth, A. Redington, J. Bousquet, P. Godard, S. Holgate, and J.M. Polak. 1993. Induction of nitric oxide synthase in asthma. Lancet. 342:1510-1513.

15. Yang, X., N. Chowdhury, B. Cai, J. Brett, C. Marboe, R.R. Sciacca, R.E. Michler, and P.J. Cannon. 1994. Induction of myocardial nitric oxide synthase by cardiac allograft rejection. J. Clin. Invest. 94:714-721.

16. Langrehr, J.M., N. Murase, P.M. Markus, X. Cai, P. Neuhaus, W. Schraut, R.L. Simmons, and R.A. Hoffman. 1992. Nitric oxide production in host-versus-graft and graft-versus-host reactions in the rat. J. Clin. Invest. 90: 679-683.

17. Misko, T.P., W.M. Moore, T.P. Kasten, G.A. Nickols, J.A. Corbett, R.G. Tilton, M.L. McDaniel, J.R. Williamson, and M.G. Currie. 1993. Selective inhibition of the inducible nitric oxide synthase by aminoguanidine. Eur. J. Pharmacol. 233:119-125.

18. Worrall, N.K., W.D. Lazenby, T.P. Misko, T.-S. Lin, C.P. Rodi, P.T Manning, R.G. Tilton, J.R. Williamson, and T.B. Ferguson, Jr. 1995. Modulation of in vivo alloreactivity by inhibition of inducible nitric oxide synthase. $J$. Exp. Med. 181:63-70.

19. Shiraisi, T., S.R. DeMeester, N.K. Worrall, J.H. Ritter, T.P. Misko, T.B. Ferguson, Jr., J.D. Cooper, and G.A. Patterson. 1995. Inhibition of inducible nitric oxide synthase ameliorates rat lung allograft rejection. J. Thorac. Cardiovasc. Surg. 110:1449-1460.

20. Cooke, J.P., A.H. Singer, P. Tsao, P. Zera, R.A. Rowan, and M.E. Billingham. 1992. Antiatherogenic effect of L-arginine in the hypercholesterolemic rabbit. J. Clin. Invest. 90:1168-1172.

21. Lemström, K.B., P.T. Aho, C.A. Bruggeman, and P.J. Häyry. 1994. Cytomegalovirus infection enhances mRNA expression of platelet-derived growth factor-BB and transforming growth factor- $\beta 1$ in rat aortic allografts. Possible mechanism for cytomegalovirus-enhanced graft arteriosclerosis. Arterioscler. Thromb. 14:2043-2052.

22. Chomczynski, P., and N. Sacchi. 1987. Single-step method of RNA isolation by acid guanidinum thiocyanate-phenol-chloroform extraction. Anal. Biochem. 162:156-159.

23. Moshage, H., B. Kok, J.R. Huizenga, and P.L.M. Jansen. 1995. Nitrite and nitrate determinations in plasma: a critical evaluation. Clin. Chem. 41:892-896.

24. Schmidt, H.H.H.W., T.D. Warner, M. Nakane, U. Förstermann, and F. Murad. 1992. Regulation and subcellular location of nitric oxide synthases in RAW264.7 macrophages. Mol. Pharmacol. 41:615-624.

25. Hertz, M.I., J. Jessurun, M.B. King, S.K. Savik, and J.J. Murray. 1993. Reproduction of the obliterative bronchiolitis after heterotopic transplantation of mouse airways. Am. J. Pathol. 142:1945-1951.

26. Reichenspurner, H., X. Huang, V. Soni, R. Shorthouse, G. Berry, and R.E. Morris. 1995. Pathogenesis and treatment of obliterative airway disease after heterotopic tracheal allograft and xenograft transplantation. Surg. Forum. 156:456-458.

27. Uyama, T., J.B. Winter, G. Groen, C.R.H. Wildevuur, Y. Monden, and J. Prop. 1992. Late airway changes caused by chronic rejection in rat lung allografts. Transplantation (Baltimore). 54:809-812.

28. King, M.B., J. Jessurun, S.K. Savik, J.J. Murray, and M.I. Hertz. 1997. Cyclosporine reduces development of obliterative bronchiolitis in a murine heterotopic airway model. Transplantation (Baltimore). 63:528-532.

29. Pinsky, D.J., M.C. Oz, S. Koga, Z. Taha, M.J. Broekman, A.J. Marcus, H. Liao, Y. Naka, J. Brett, P.J. Cannon, et al. 1994. Cardiac preservation is enhanced in a heterotopic rat transplant model by supplementing the nitric oxide pathway. J. Clin. Invest. 93:2291-2297.

30. Cooke, J.P., and P.S. Tsao. 1993. Cytoprotective effects of nitric oxide. Circulation. 88:2451-2454.

31. Russel, M.E., A.F. Wallace, L.R. Wyner, J.B. Newell, and M.J. Karnovsky. 1995. Upregulation and modulation of inducible nitric oxide synthetase in rat cardiac allografts with chronic rejection and transplant arteriosclerosis. Circulation. 92:457-464.

32. Akyürek, L.M., B.C. Fellström, Z.-q. Yan, G.K. Hansson, K. Funa, and E. Larsson. 1996. Inducible and endothelial nitric oxide synthase expression during development of transplant arteriosclerosis in rat aortic grafts. Am. J. Pathol. 149:1981-1990.

33. Naruse, K., K. Shimizu, M. Marumatso, Y. Toki, Y. Miyazaki, K. Okumura, H. Hashimoto, and T. Ito. 1994. Long-term inhibition of NO synthesis promotes artherosclerosis in the hypercholesterolemic rabbit aorta. Arterioscler. Thromb. 14:746-752.

34. Hou, J.H., H. Kato, R.A. Cohen, A.V. Chobanian, and P. Brecher. 1995. Angitensin II-induced cardiac fibrosis in the rat increased by chronic inhibition of nitric oxide synthase. J. Clin. Invest. 96:2469-2477.

35. McNamara, D.B., B. Bedi, H. Aurora, L. Tena, L.J. Ignarro, P.J. Kadowitz, and D.L. Akers. 1993. L-arginine inhibits balloon catheter-induced intimal hyperplasia. Biochem. Biophys. Res. Commun. 193:291-296.

36. Gregory, C.R., J.P. Cooke, J.D. Patz, E.R. Berryman, R. Shorthouse, and R.E. Morris. 1996. Enhanced nitric oxide production induced by the admin- 
istration of L-arginine does not inhibit arterial neointimal formation after overwhelming alloimmune injury. J. Heart. Lung Transplant. 15:58-66.

37. Langrehr, J.M., D.A. White, R.A. Hoffman, and R.L. Simmons. 1993. Macrophages produce nitric oxide at allograft sites. Ann. Surg. 218:159-166.

38. Kourembanas, S., L.P. McQuillan, G.K. Leung, and D.V. Faller. 1993. Nitric oxide regulates expression of vasoconstrictors and growth factors by vascular endothelium under both normoxia and hypoxia. J. Clin. Invest. 92:99-104.

39. Hertz, M.I., C.A. Henke, R.E. Nakhleh, K.R. Harmon, W.A. Marinelli, J.M.K. Fox, S.H. Kubo, S.J. Shumway, R.M. Bolman, III, and P.B. Bitterman. 1992. Obliterative bronchiolitis after lung transplantation: a fibroproliferative disorder associated with platelet derived growth factor. Proc. Natl. Acad. Sci. USA. 89:10385-10389.

40. Al-Dossari, G.A., J. Jessurun, R. Morton Bolman, III, R.K. Vibhu, M.B. King, J.J. Murray, and M.I. Hertz. 1995. Pathogenesis of obliterative bronchiolitis: Possible role of platelet derived growth factor and basic fibroblast growth factor. Transplantation (Baltimore). 59:143-145.

41. Kariya, K.-i., Y. Kawahara, S.-i. Araki, H. Fukuzaki, and Y. Takai. 1989. Antiproliferative action of cyclic GMP-elevating vasodilators in cultured rabbit smooth muscle cells. Atherosclerosis. 80:143-147.

42. Garg, U.C., and A. Hassid. 1989. Nitric oxide-generating vasodilators and 8-bromo-cyclic guanosine monophosphate inhibit mitogenesis and prolifer- ation of cultured rat vascular smooth muscle cells. J. Clin. Invest. 83:1774-1777.

43. Radomski, M.W., R.M.J. Palmer, and S. Moncada. 1990. An L-arginine/ nitric oxide pathway present in human platelets regulates aggregation. Proc. Natl. Acad. Sci. USA. 87:5193-5197.

44. Murohara, T., S.J. Parkinson, S.A. Waldman, and A.M. Lefer. 1995. Inhibition of nitric oxide biosynthesis promotes P-selectin expression in platelets. Arterioscler. Thromb. Vasc. Biol. 15:2068-2075.

45. Kubes, P., M. Suzuki, and D.N. Granger. 1991. Nitric oxide: An endogenous modulator of leukocyte adhesion. Proc. Natl. Acad. Sci. USA. 88:46514655 .

46. Sayegh, M.H., E. Akalin, W.W. Hancock, M.E. Russel, C.B. Carpenter, P.S. Linsley, and L.A. Turka. 1995. CD28-B7 Blockade after alloantigenic challenge in vivo inhibits Th1 cytokines but spares Th2. J. Exp. Med. 181:1869-1874.

47. Taylor-Robinson, A.W., F.Y. Liew, A. Severn, D. Xu, S.J. McSorley, P. Garside, J. Padron, and R.S. Phillips. 1994. Regulation of the immune response by nitric oxide differentially produced by $\mathrm{T}$ helper type 1 and $\mathrm{T}$ helper type 2 cells. Eur. J. Immunol. 24:980-984.

48. Wei, X.-q., I.G. Charles, A. Smith, J. Ure, G.-j. Feng, F.-p. Huang, D. $\mathrm{Xu}$, W. Muller, S. Moncada, and F.Y. Liew. 1995. Altered immune responses in mice lacking inducible nitric oxide synthase. Nature. 375:408-411. 